\title{
Redesign of Work Environment with Ergonomics Intervention to Reduce Fatigue
}

\author{
Sajiyo, ${ }^{1}$ \\ Department of Industrial Engineering, \\ Universitas 17 Agustus Surabaya, Surabaya, Indonesia \\ M Adhi Prasnowo, ${ }^{2}$ \\ Department of Industrial Engineering, \\ Universitas Maarif Hasyim Latif, Sidoarjo, Indonesia \\ ${ }^{2}$ ORCID: 0000-0001-7283-976X
}

\begin{abstract}
The Research is to evaluate the redesign of the working environment with ergonomic intervention to decrease the fatigue of employees at "Batik Putri Luwes" home industry. This is an experimental research that has the same subject design to cope the problem that is faced by female employees at Home Industry. In this research, ergonomic interventions have been set up at workplace environment, such as (1) installation of exhaust systems to set up the air circulation, the humidity, and temperature of air in the workplace; (2) reengineering to the lamps configured to provide sufficient lighting in the workplace. The essence of this research is the ergonomic intervention to the workplace environment. The excellence of this research is the achievement of collaboration and commitment from both employer and employees, and the management as well. Therefore, this research has a beneficial bargain that can increase the quality of the organization.
\end{abstract}

Keywords: Ergonomic intervention, Redesign, Reduce fatigue, Home industry

\section{INTRODUCTION}

Asean Economic Community (AEC), which was proclaimed Indonesia in late 2015 had a significant impact, to sensitize the people of Indonesia in the face of competing for economic challenges, and the challenges of competence in the times to come. The spirit AEC has been raging across Indonesia did not miss for people in rural areas. Commitment to open trade with ASEAN member countries in Asean Free Trade Area (AFTA) In general, the industrial sector in Indonesia can absorb a workforce of more than $60 \%$ (Sajiyo, 2008). In particular batik industry become the foundation of income, especially rural women, although such work as work-stream, after planting and carrying out household chores. On the other hand, because the work environment is not ergonomic, the batik makers who complain fatigue when doing work activities. Mother-housewife, have jobs other than as batik craftsmen capable of sustaining the family economy of more than $50 \%$ of the daily needs of the economy. The batik craftsmen to work more efficiently is necessary to design the batik workspace ergonomically.

Background issue in this study is that the home industry "Batik Putri Luwes" in the village of Pungsari, District Plupuh, Sragen, Central Java. A Batik SMEs that are working to improve the competitiveness to follow the development of the Asean Free Trade Area (AFTA). Although the quality of the production is already qualified, but in the attempt to experience constraints are as follows: (1) The production targets are still not being met, (2) many craftsmen (employees) who complained of fatigue, and (3) many craftsmen (employees ) who often complain of headache, neck pain, shoulder pain, pain in the upper arm and pain in the spine. To overcome the constraints faced by the craftsmen (employees) in the home industry "Batik Putri Luwes" it is necessary to do research on "Redesign of Work Environment With Ergonomics Intervention to Reduce Fatigue" at Home Industry Batik Princess Supple in Sragen, Central Java.

In this research conducted ergonomics interventions which include: (1) setting the position of the light, (2) Installation of the exhaust fan, (3) setting facility layout work, and (4) setting attitude and working positions. The approach taken in this study is the holistic and participatory approach. The technology used in ergonomics intervention is appropriate technologies that have local knowledge, assessed comprehensively, so that it meets the criteria of ergonomics and technically and economically feasible, do not conflict with the social and cultural conditions, as well as environmentally friendly.

\section{RESEARCH QUESTIONS}

Based on the background problems and interventions ergonomics of the above. The problem in this research are: (1) How much influence the intervention of ergonomics to decrease fatigue?, (2) How much affect the intervention of ergonomics to the decrease musculoskeletal disorders?, and 
(3) How much influence ergonomic interventions on productivity improvement?

\section{OBJECTIVE}

Based on the formulation of the problem in the studies above. The purpose of this study are: (1) To determine the effects of ergonomic interventions to decrease fatigue, (2) To determine the effects of ergonomic interventions to decrease musculoskeletal disorders, and (3) To determine the effects of ergonomic interventions to increase labor productivity,
MINDSET, FRAMEWORK CONCEPTS, AND RESEARCH HYPOTHESIS

\section{a. Mindset}

worldview on which the formulation of the problem in this research are as follows: production target is not reached, workers feel easily tired, and complained of pain in the muscle system skeletal.

\section{b. Framework Concept Research}

Having noted the background of the problem, formulation of the problem, research objectives, and the frame of mind in the study, created the conceptual framework of research as in Fig. 1 below:

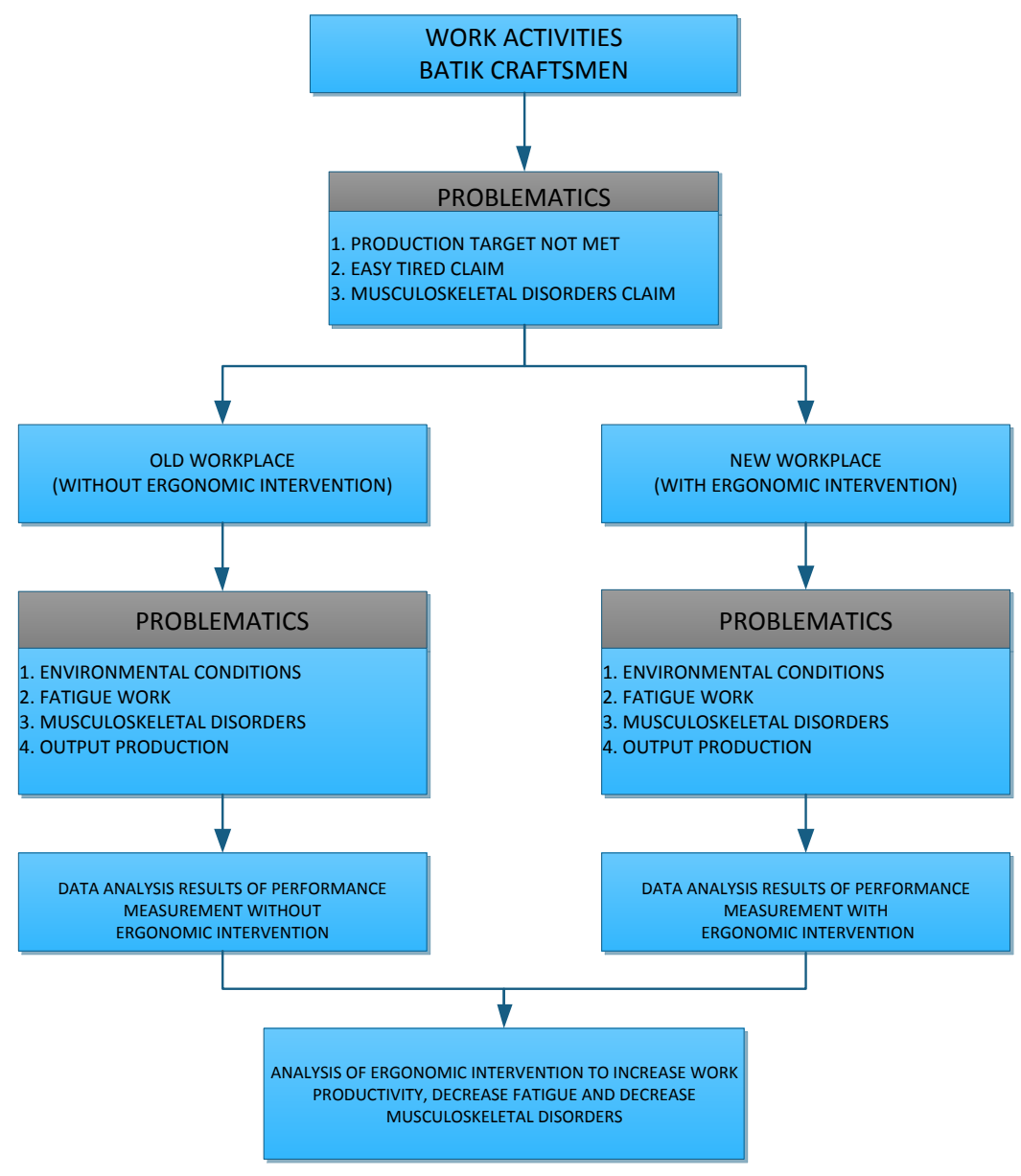

Figure 1: Research Conceptual Framework

\section{Caption :}

Intervention ergonomics performed in this study are: (1) adjust the position and intensity of light to obtain light intensity ergonomic worker positions batik craftsmen. (2) install exhaust fans to regulate air circulation, humidity and the air temperature to keep the room workers batik feel more comfortable. (3) set the position and attitude of the worker batik to reduce fatigue and musculoskeletal disorders.

\section{c. Research Hypothesis}

Based on the objectives and the conceptual framework of the research above, formulated the hypothesis of the study as follows (1) Ergonomics intervention can improve work productivity, (2) Ergonomics intervention can reduce fatigue, and (3) Ergonomics intervention can reduce musculoskeletal disorders. 


\section{RESEARCH METHODS}

\section{a. Research Design}

This Research aims to determine the influences of ergonomic interventions to increase labor productivity, decrease fatigue, and musculoskeletal disorders. This study was an experimental study, the design of the study subjects; the outline is shown in Fig. 2 below:

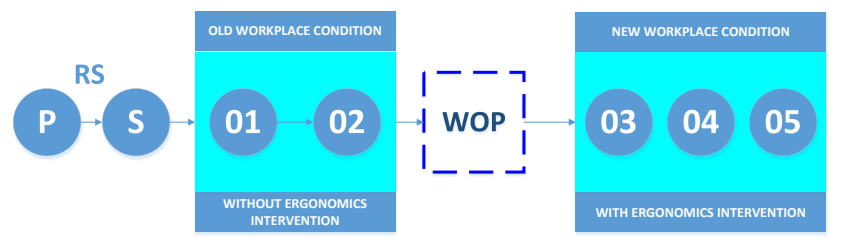

Figure 2: Study Design

Caption:

$\mathrm{P}=$ Population, $\mathrm{RS}=$ Random Sampling, $\mathrm{S}=$ Sampling, $\mathrm{O} 1=$ Preliminary observations work in conditions of old workplace, $\mathrm{O} 2$ = Final observations work in conditions of old workplace, WOP $=$ Washing Out Period during 1 working day, $\mathrm{O} 3=$ work activities in a period of adjustment to the conditions of new workplaces for 6 weekdays, $\mathrm{O} 4=$ Preliminary observations work in conditions of new workplaces, and $\mathrm{O5}$ = final observations work in conditions of new workplaces.

\section{b. Research Location and Time}

The location of this research is room batik "Batik Putri Luwes" in Hamlet: Turiswari, Village: Pungsari, district. Plupuh, Kab. Sragen, Central Java. This study was conducted over 12 days, starting date of March 7 to 19, 2016

\section{c. Population and Sample}

Population in this study is all batik totaling 12 people, and are all female, of 12 craftsmen are all taken as a sample(total sample).

\section{d. Research Variables}

variables in the study consisted of (1) the dependent variable (dependent variable) labor productivity, fatigue, and musculoskeletal disorders; (2) the independent variable (independent variable) is the condition of the old workplace, and conditions of a new workplace.

\section{e. Research Procedures}

This was done in 3 stages: (1) the preparation stage involves determining the subject of research, provide an explanation of the research process, and prepare instruments of research. (2) the implementation stages include installation of exhaust fans, the mounting position of lighting, positioning and work attitude, the measurement of fatigue, measurement of musculoskeletal disorders, and the measurement of labor productivity. (3) stages of analysis and discussion include data analysis and discussion of research results.

\section{ERGONOMICS INTERVENTION}

Ergonomics intervention in this study are as follows: (1) installation of exhaust fans; (2) the setting position and light intensity; (3) setting the position of the working attitude. As described as follows:

\section{a. Installation of Exhaust Fan}

Installation of exhaust fan by wind direction, both in the dry season the wind direction and the wind direction during the rainy season. It is intended that the air circulation in the room was working synergy with wind direction naturally are outdoors working. Batik craftmens workspace on the old conditions, only mounted 1 (one) window in the west. As in Fig. 3a below:

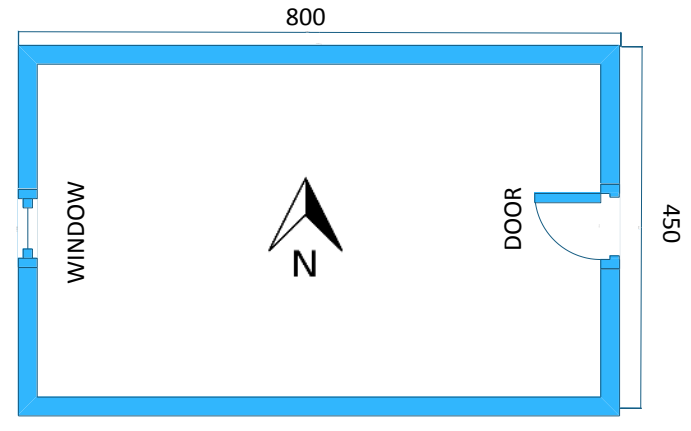

Figure 3a Old Workspace

(Before Mounted Exhaust Fan)

Workroom batik on condition of newly installed five exhaust fan. Two pieces of the exhaust fan are installed on the north side. Two pieces of the exhaust fan are installed on the south side. An exhaust fan installed on the west side. Two windows mounted on the north and south side; west side windows replaced exhaust fan. As in Fig. 3b below:

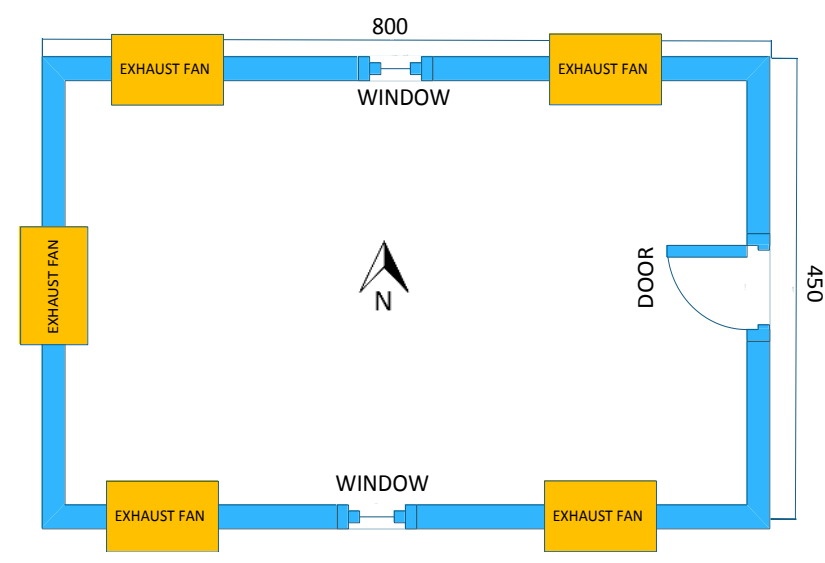

Figure 3b: New Workspace 
(After Five Mounted Exhaust fan and two windows)

Windows installed on the north and south, to adjust to the wind direction naturally. Wind direction in Central Java in the dry season moving from the south - west to north northeast, and vice versa during the rainy season moving from the north - northeast towards the south - southwest.

\section{b. Settings Lamp}

Settings lamp position to meet the needs of light and avoid glare, to enable workers to work more comfortably. Old workspace is installed only one lamp placed in the middle of the room. As in Fig. 4a below:

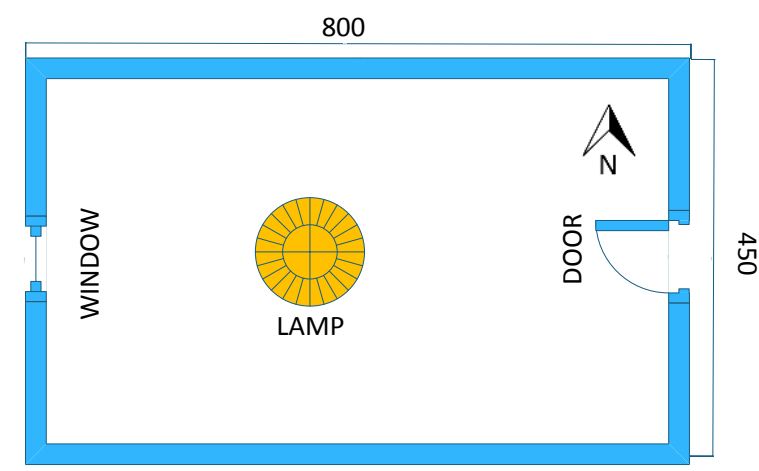

Figure 4a: Old Workspace

(only installed one lamp)

Newly installed Workroom 2 lamps to meet the needs of light, so that the workspace is bright and no glare. As in Fig. 4b below:

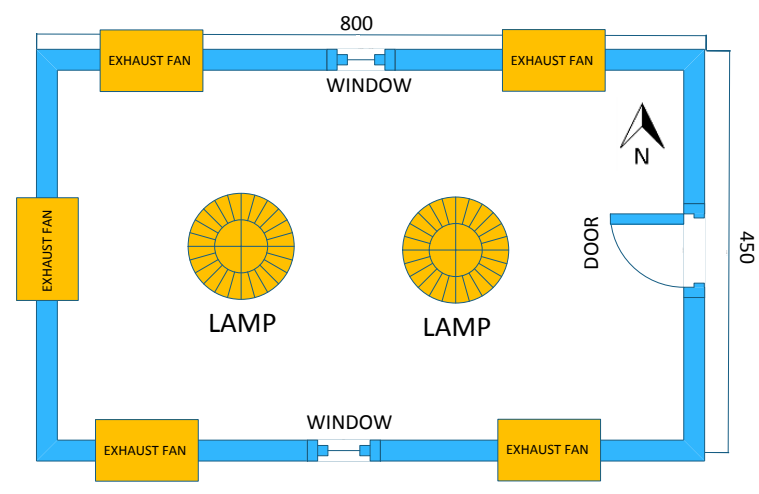

Figure 4b: New Workspace

(Once installed two lights)

\section{a. Working Position Adjustment}

Settings to adjust the working position with a circulation of the wind and the light source, to more luminous, less glare and heat. Long working position consists of three (3) groups, with each group of 4 people, and a working position in the middle of the room. As in Fig.5a below:

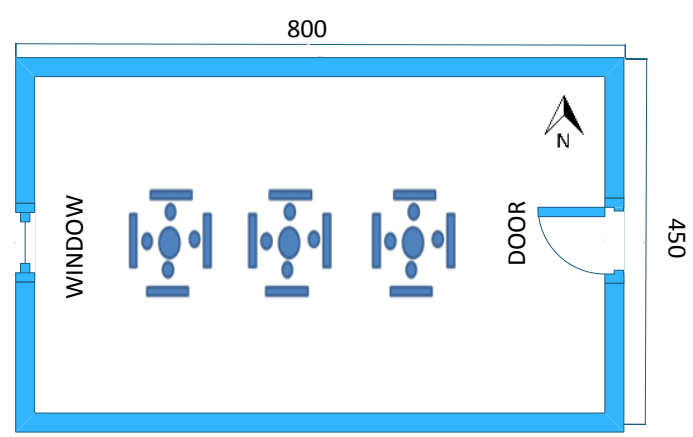

Figure 5a: Old Working Position

(Every group of 4 people, a position in the middle of the room)

Position new work consists of four (4) groups, each group consisting of three people, working for position 2 (two) groups on the north side, and two (2) group on the south side. As in the fig. $5 \mathrm{~b}$ below:

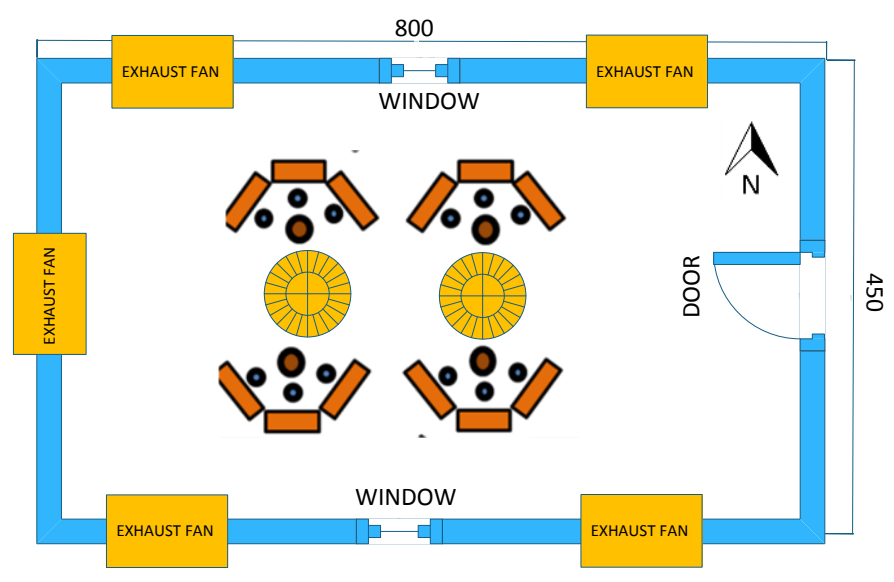

Figure 5b: New Work Position

(Each group has three positions in the north and south side of the window)

Caption:

$\square=$ Ongkek ( Place Of batik )
$=$ wajan ( Place Of plastisin )
$=$ Craftsmen position
$=$ Lamps position

\section{DATA ANALYSIS}

\section{a. Data Analysis Light Intensity}

Light intensity data analysis result obtained the following results: 
a) Average intensity of light on the conditions of work space of time (before ergonomics intervention) is 167.44 Lux.

b) Average light intensity at the new working conditions (after an ergonomic intervention) is 350.05 Lux.

\section{b. Humidity Data Analysis}

Data analysis results humidity is obtained as follows:

a) Average humidity at ambient conditions of work a long time (before intervention ergonomics) is $70.19 \%$.

b) average humidity on new working conditions (after ergonomic intervention) is $58.36 \%$

\section{c. Air Temperature Data Analysis}

Air temperature data analysis result obtained the following results:

a) Average -rata moist air at ambient conditions of work a long time (before ergonomics intervention) is $29.91{ }^{\circ} \mathrm{C}$.

b) Average air temperature at the new working conditions (after ergonomic intervention) is $26.07{ }^{\circ} \mathrm{C}$.

\section{d. Wind Speed Data Analysis}

Wind speed data analysis results obtained the following results:

a) Average humidity at ambient conditions of work a long time (before ergonomics intervention) was 0.10 meters/second.

b) Average wind speed on working conditions the new (after ergonomics intervention) is 0.15 meters/second.

\section{e. Subjective Fatigue Data Analysis}

Data analysis results of subjective fatigue obtained the following results:

a) Average score of subjective fatigue during breaks on long working ambient conditions (before ergonomics intervention) is 1.21. Average score of subjective fatigue when working on old work room conditions (before ergonomics intervention) is 3.20 .

b) Average score of subjective fatigue during breaks on new working conditions of the room (after ergonomic intervention) was 1.14. Average score of subjective fatigue while working on new working conditions of the room (after ergonomics intervention) is 1.99 .

\section{f. Pulse Data Analysis}

Data analysis result pulse is obtained as follows:

a) Average resting pulse rate (RPR) on the condition of the working space of time (before ergonomics intervention) was
77.60 beats/minute and average pulse work (PW) on the condition of the working space of time (before ergonomics intervention) is 150.71 beats/minute.

b) Average resting pulse rate (RPR) on new work room conditions (after ergonomic intervention) was 77.40 beats / min. Average pulse work (PW) on new working conditions of the room (after ergonomics intervention) is 113.80 beats / $\min$.

c) Average increase in pulse rate of work (IPRW) on the condition of the working space of time (before ergonomics intervention) is $60.55 \%$. The average increase in pulse rate of work (IPRW) on new working conditions of the room (after ergonomics intervention) is $29.69 \%$.

\section{g. Musculoskeletal Disorders Data Analysis}

Data analysis results of subjective fatigue obtained the following results:

a) Average musculoskeletal disorder score at rest on the old workroom conditions (before ergonomics intervention) is 1.38. The average score of musculoskeletal disorders while working in the old work room conditions (before ergonomics intervention) is 3.25 .

b) The average score of musculoskeletal disorders during breaks on new working conditions of the room (after ergonomics intervention) is 1.29 , The average score of musculoskeletal disorders while working on new working conditions of the room (after ergonomics intervention) is 1.99 .

\section{h. Production Ouput Data Analysis}

Production Output data analysis obtained the following results:

a) The average production output at the room condition old work (before ergonomics intervention) is 2.02 strands/person/week. The average output of production on new working conditions of the room (after ergonomics intervention) is 3.30 strands/person/week.

b) Average increase in production output after an ergonomic intervention was $63.37 \%$.

\section{DATA ANALYSIS RESULTS DISCUSSION}

\section{a. Light Intensity Data Analysis Discussion}

The average light intensity at the old workroom conditions (before ergonomics intervention) is 167.44 Lux, the light intensity level of accuracy suitable for the little employment. The average intensity of a new light on the working conditions (after an ergonomic intervention) is 350.05 Lux; the light intensity is suitable for jobs with high accuracy. Batik craftsmen work including job categories with high precision. Thus ergonomics interventions can increase the intensity of light according to the level of precision of the work. 


\section{b. Humidity Data Analysis Discussion}

The average humidity in the room condition of old work (before ergonomics intervention) is $70.19 \%$, the humidity is very high not appropriate with the recommended ergonomics is a maximum of $60 \%$. And average humidity on new working conditions (after an ergonomic intervention) is $58.36 \%$, the moisture following the recommended ergonomics is $40 \%-60 \%$ in the rainy season, and $40 \%-50 \%$ in the dry season.

\section{c. Air Temperature Data Analysis Discussion}

Average air temperature in the room condition of old work (before ergonomics intervention) is $29.91{ }^{\circ} \mathrm{C}$; the air temperature is very high does not comply with the recommended ergonomics is a maximum of $26^{\circ} \mathrm{C}$. And the average temperature in the new working conditions (after an ergonomic intervention) is $26.07{ }^{\circ} \mathrm{C}$, the air temperature by the recommended ergonomics is $20{ }^{\circ} \mathrm{C}-24{ }^{\circ} \mathrm{C}$ during the rainy season, and $23{ }^{\circ} \mathrm{C}-26^{\circ} \mathrm{C}$ in the dry season.

\section{d. Wind Speed Data Analysis Discussion}

The average wind speed at the old workroom conditions (before the ergonomic intervention) was 0.10 meters/second, the very low wind speeds are not by the recommended ergonomics is at least 0.15 meters/second. The average wind speed in the new working conditions (after an ergonomic intervention) is 0.15 meter/second wind speed by the recommended ergonomics 0.15 meter/second during the rainy season, and 0.25 meter/second on the dry season.

\section{e. Subjective Fatigue Data Analysis Discussion}

a) The average score of subjective fatigue at rest at ambient conditions of old work (before ergonomic intervention) is 1.21. Shows that workers "not tired" at rest, and the average score of subjective fatigue when working on old work room conditions (before ergonomic intervention) is 3.20. Shows workers in conditions of "extreme fatigue". The worker fatigue means really a result of work activities.

b) The average score of subjective fatigue during breaks on new working conditions of the room (after ergonomic intervention) is 1.14. Shows that workers "not tired" and the average score of subjective fatigue while working on new working conditions of the room (after ergonomic intervention) is 1.99. Shows "not tired". Means that the working conditions are not tired when working on room conditions new working really influence of intervention ergonomics.

\section{f. Pulse Data Analysis Discussion}

a) Average resting pulse rate (RPR) at ambient conditions of work a long time (before ergonomic intervention) was 77.60 beats / min. Show "light workload", and the average pulse work (PW) on the condition of the working space of time (before ergonomic intervention) is 150.71 beats / min. Showed "a very heavy workload."

b) average resting pulse rate (RPR) on new work room conditions (after ergonomic intervention) was 77.40 beats / min. Show "light workload",and the average pulse work
(PW) on new working conditions of the room (after ergonomic intervention) is 113.80 beats / min. Show " moderate workload". So changes in the workload of the "very hard" on the condition of the workspace longer be "moderate" at the room condition new working really a result of the intervention of ergonomics.

c) average increase in pulse rate of work (IPRW) at ambient conditions of old work ( before the intervention ergonomics) is $60.55 \%$. Shows the condition of the workers "tired",and the average increase in pulse rate of work (IPRW) on new working conditions of the room (after ergonomic intervention) is $29.69 \%$. Shows that workers in a state of "not tired".So change "tired" when working on the conditions of work space of time, become "tired" at the time worked at the room condition new work strongly as a result of the intervention of ergonomics.

\section{g. Disorders Musculoskeletal Data Analysis Discussion}

a) Average score disorders musculoskeletal conditions of the room during breaks at work a long time (before ergonomic intervention) is 1.38. Shows that workers "not disturbed", and the average score of musculoskeletal disorders while working on the old work room conditions (before ergonomic intervention) is 3.25 . Shows that workers "very disturbed".

b) The average score of musculoskeletal disorders during breaks on new working conditions of the room (after ergonomic intervention) is 1.29. Shows workers "not disturbed", and the average score of musculoskeletal disorders while working on new working conditions of the room (after ergonomic intervention) is 1.99. Shows "not disturbed". The change from a very disturbed while working on the conditions of work space of time, and not compromised on the condition of the new workspace, really a result of the intervention of ergonomics.

\section{h. Output Production Data Analysis Discussion}

a) Average production output at ambient conditions of old work ( before ergonomic intervention) is 2.02 strands/person/week. The average output of production on new working conditions of the room (after ergonomic intervention) is 3.30 strands/person/week. It shows that ergonomic interventions can increase the production output from an average of 2.02 strands/person/day form the strands 3.30/person/day.

b) Average increase in production output after an ergonomic intervention was $63.37 \%$, The increase in the production output actually as a result of the intervention of ergonomics.

\section{CONCLUSIONS AND RECOMMENDATIONS}

\section{a. Conclusions}

Redesign Work Environment Approach ergonomics can reduce fatigue of the category of "Very Tired" to "Not Tired",lowering the musculoskeletal disorders of "Severely 
International Journal of Applied Engineering Research ISSN 0973-4562 Volume 12, Number 7 (2017) pp. 1237-1243

(C) Research India Publications. http://www.ripublication.com

Impaired" to "Not Disturbed", and can increase the production output of "63, 37\% ".

\section{b. Suggestions}

To further improve the efficiency and productivity of batik makers, need to do further research on the design of equipment batik among others: the work station design of the batik (ongkek), instrument pour wax (canting), heating the wax (wajan), and wok burner (pawonan).

\section{REFERENCES}

[1]. Adiputra, 1998. Ergonomi Makro. Denpasar : Program Studi Ergonomi Fisiologi Kerja Program Pascasarjana Universitas Udayana.
[2]. Grandjean 2000. Fitting The Taqsk To he Man. A Textbook Of Ocupational Ergonomics : Taylor \& Francis Inc. [3]. Manuaba, 1992. Pegaruh Ergonomi Terhadap Produktivitas Kerja. Makalah Semnar Perkembangan Mutakhir Perkemangan Ilmu Kedoteran. Jakarta : 30 Januari 1992

[4]. Manuaba, 2000. Ergonomi Keselamatan dan Kesehatan Kerja. Proceding Seminar Nasional Ergonomi di Surabaya. Penerbit Guna Widya.

[5]. Sajiyo, 2008. Desain Kerja Dengan Pendekatan Ergonomi Untuk Meningkatkan Produktivitas Kerja Pada Industri Rokok Di Jawa Timur. Denpasar : Disertasi Program Pascasarjana Universitas Udayana

[6]. Suma'mur, 1989. Ergonomi Untuk Produktivitas Kerja. Jakarta : Penerbit Haji Mas Agung 